\title{
Post Otistik İktisat Hareketi: Eleştirel Bir Yaklaşım
}

\author{
HASAN UMUtLU (10) 1
}

Başvuru: 20.01.2020; Düzenlenme: 11.03.2020; Kabul: 26.04.2020

\begin{abstract}
Marjinalist devrim sonucunda ortaya çıkan Neoklasik iktisat akımı Amerikan kapitalizminin varlığ ile iktisat eğitimi ve iktisat çalı̧malarında egemen durumdadır. Ana akımın ideolojik ve felsefi kabulleri Uluslararası Para Fonu ve Dünya Bankası politikalarından Nobel iktisat ödüllerine kadar etkisini hissettirmiştir. Ana akım iktisat akımı iktisat eğitiminde kendi ideolojik ve felsefi yaklaşımlarını dikta olarak ögretmektedir. Bunun için psikoloji, sosyoloji, siyaset bilimi, tarih, iktisadi düşünce okulları gibi sosyal bilimleri iktisadın içerisinden soyutlamıştır. Bu kapsamda iktisatta artan matematik kullanımı, gerçek hayattan kopuk kuramları ve çoğulculuk problemi ana akım iktisada eleştirileri artırmıştır. 2000 yılında Fransa'da öğrenciler tarafından hazırlanan bildiri neticesinde Post Otistik Iktisat Hareketi ile bu eleştiriler organize bir hal almıştır. Ana akım iktisadı çeşitli şekillerde eleştiren hareket kısa sürede destek bularak dünyaya yayılmıştır. Post Otistik Iktisat Hareketi "otistik" isminden Fransa'da ortaya çıkmasına kadar düşünülmüstür. Çalışmada ana akım iktisat akımının Dünya Bankası ve IMF politikalar ile meydana getirdiği gelir dağılımındaki adaletsizliklerden, eşitsizliklerden bahsedilmiştir. Çalışmada matematiğin iktisat için amaç haline geldiği sonucuna ulaşılmıştır. Neoklasik iktisadın ideolojik ve felsefi olarak etkisi iktisat eğitiminde ve yayınlarında görülmüstür. Neoklasik iktisadın ideolojik ve felsefi düşüncesinin IMF, Dünya Bankası ve Nobel gibi kuruluşlara etki ettiği belirtilmiştir.
\end{abstract}

JEL kodları: A11, A12, A14, A20, B13

Anahtar kelimeler: Neoklasik iktisat, Post Otistik İktisat, Sosyal Bilimler, İktisat ve Matematik

\section{Giriş}

Marjinalist bir devrim sonucunda ortaya çıkan Neoklasik iktisat okulu yaklaşık yüz yıldır ana akım iktisat olarak kendini hissettirmiştir. Her ne kadar belli dönemlerde ağır eleştirilere maruz kalsa da ideolojik yaklaşımdan iktisat eğitimine, kurumsal ödüllerden Uluslararası Para Fonu (IMF)

1 İktisat ABD Programı, Sosyal Bilimler Enstitüsü, Eskişehir Osmangazi Üniversitesi, Türkiye. (e-mail: hasandnyl@gmail.com) ve Dünya Bankası politikalarına kadar kendini hissettirmeye devam etmektedir. Neoklasik ekol ideolojik, felsefi, metodolojik anlamda Klasik iktisadi ekol ile benzer yanları olmakla birlikte ondan ayrılan keskin görüşlere de sahiptir. Belli kısitlarla sağlanan maksimizasyon, azalan marjinal fayda ilkesi, değer kuramı, öznel bir değer kuramını benimsemiş olması ve ideolojik, felsefi görüşlerinin evrensel yasa haline getirilmesi Neoklasik ekolün iktisat bilimine katkıları olarak belli başlı alanlar olarak görülebilir. Rasyonel bireycilik anlamında 
ele alınan politik davranışlarda bu kapsamda değerlendirilebilir. Bireyin iktisadi kararlarında rasyonel hareket etmesi diğer bir ifadeyle kendi refahını artırmak için, iktisadi çıkarına uygun davranması Neoklasik iktisat ekolünün belirleyicilerinden olmuştur. Bunlara ek olarak mikro ve makro iktisat eğitim alanında hâkim görüş haline gelmesi de hem kendi ideolojik yaklaşımları hem de egemen iktisat olma yolunda ilerlemeleri için önemli bir alan olmuştur. Neoklasik iktisat ekolü kendi kuramlarını evrensel hale getirmeye çalışmıştır. Bu yüzden de iktisat bilimini, sosyal bilimlerden iyice uzaklaştırıp doğa bilimleri ile yaklaştırmaya çalışmışlardır. İktisadın doğa bilimleri olan fizik ve matematik bilimleri ile ilişkisi yeni olmamakla birlikte Neoklasik iktisat akımı ile iktisat bilimi içinde bir dönüşüm yaşamıştır.

Özellikle 2. Dünya Savaşı yıllarından sonra iktisatta artan matematik ve ekonometrik analizler, uygulamalar, Neoklasik iktisat ekolün iktisat bilimini matematik, fizik gibi doğa bilimleriyle yakınlaştırıp evrensel yasa kuramını hayata geçirme çabası dikkat çekmiştir. Bunun dışında mikro ve makro iktisat eğitiminde egemen iktisat rolü ile Neoklasik iktisat dışında diğer ideolojik ve felsefi görüşlere yer verilmemesi ve Neoklasik iktisadın kuramlarının gerçek hayatla olan kopukluğu 2000 yllında Post Otistik İktisat hareketinin doğmasına sebep olmuştur. Post Otistik İktisat hareketi siradan bir eleştirel yaklaşımla hazırlanmamış "otistik" kelime anlamının hayali dünyayı yansitmasindan, hareketin tarihsel süreçte radikal eğilimlerin daima olduğu Fransa'da ortaya çımasına kadar kapsamlı ve bilinçli olarak hazırlanmış bir hareket olmuştur. İktisat eğitiminde yaşanan egemen anlayış, gerçek dünyadan kopuk görüşler ve sosyal bir birey olan insanın odağındaki iktisat biliminin sosyal bilimlerden uzaklaşıp doğa bilimlerine yaklaşması Post Otistik İktisat hareketinin Neoklasik iktisat hareketi için temelde aldığı eleştirel bakışlar olup iktisat akademisyenlerine de net bir çağrıda bu- lunulmuştur. $\mathrm{Bu}$ hareketin organize şekilde hazırlanıp eleştirilerin iktisat bilimi için mantık içerisinde olması hareketin karşılık bulup dünyada ses getirmesine ve ünlü iktisatçıların da harekete destek vermelerine neden olmuştur.

Doğa ve sosyal bilimlerin alt disiplinleri diğer bilimlerle ilişki içindedir. Bu durum iktisat bilimi içinde geçerlidir. Sadece kendi alanı olan sosyal bilimlerle değil doğa bilimleriyle de ilişkisi eskiye dayanmış olup A Smith gibi iktisadın önde gelen iktisatçılarının fizik ve matematik ile iktisadı beraber kullanmaları, örneklendirmelerinde yer vermeleri garipsenmemiştir. 2. Dünya Savaşı'ndan yeni çıkılması ve ekonomik anlamda yakın denilebilecek zamanda bir kriz yaşanması iktisadı bir zorlamaya itmiştir. Kriz sonrasında çabuk ve pratik çözümler için matematiğin ve ekonometrinin iktisatta kullanılması cazip görülmüsstür. Ancak Neoklasik iktisat ekolü kendi yasalarını evrenselleştirmek adına iktisatla doğa bilimlerinin ilişkisinin bir araç dahilinde gerçekleşmesini deyim yerindeyse kullanarak fizik ve matematik gibi doğa bilimlerini iktisat için amaç haline dönüştürerek iktisadı adeta matematiğin alt dalı olarak kullanma sınırına kadar ulaşmıştır.

Bu kapsamda çalı̧̧mada Neoklasik iktisat ekolünün iktisat bilimine getirdikleri yeniliklerden, bu yenilikler neticesinde eleştirel görüşlerin arttığından bahsedilmeye çalışlacaktır. Neoklasik iktisat ekolüne getirilen eleştirilerin şiddetinin artmasıyla birlikte organize şekilde oluşan Post Otistik İktisat hareketinin ortaya çıkışına ve savunduğu eleştirel yaklaşımlara değinilecektir. Neoklasik iktisadın evrensel yasa kapsamında iktisatta artan matematik ve ekonometri kullanımlarının doğuş sürecini, iktisadın diğer bilim dallarıyla ilişkisi kapsaminda ele alarak iktisatta matematik kullanımı üzerinde durulacaktır. En sonunda ise Neoklasik iktisadın egemen iktisat görüş çerçevesinde mikro ve makro iktisat eğitimi dışında kurumsal ödüllerde dahi ön plana çıktığından önemli bir literatür çalışması ile 
bahsedilmeye çalışılacaktır.

\section{Klasik İktisat Akımına Karşı Gelişen Görüşler}

Klasik iktisat okulu Kapitalist sistemin organize hale gelmesini sağlayan, A Smith ile birlikte ortaya çıkan, üretim, arz odaklı bir yaklaşımdır. Bu dönemde ticari faaliyetlerde yaşanan artış ve üretim tekniklerindeki yükseliş müdahalecilik görüşleriyle ön plana çıkan Merkantilizmin yetersiz kalmasına neden olmuştur. Serbest piyasa sistemine dayanan, liberal ekonomi politikasını savunan Klasik iktisadi okul toplum için rekabetin faydalı olacağını savunmuştur. Çeşitli eleştiri ve aşamalardan geçerek 1929 Ekonomik Buhran'a kadar piyasada söz sahibi olan Klasik okul, yaşanan kriz sonrasından etkinliğini yitirmiştir. Ekoller ya da okullar ortaya çıtığı dönemle sınırlı kalmayıp sonradan gelişme sağlayabilmekte ya da çeşitli görüşlerin düzenlenmesiyle yeni isimlerle devam edebilmektedirler. Klasik iktisat okulu da bunlardan biri olup devam eden süreçte Klasik iktisat okulunun görüşlerinden tamamen ayrılan ya da belli bazı noktalarda eleştiri getiren üç temel görüşe değinilecektir; Marksist ekol, Neoklasik ekol ve Keynesyen ekol.

Klasik iktisat okuluna ya da kapitalizme en sert eleştiri K. Marx tarafindan gerçekleştirilmiştir. Ekonomide yaşanan birtakım sosyal gelişmelere karşın işçi sınıfı hala beklenen refah seviyesine sahip olamamış; piyasada konjonktür dalgalanmaları ve ciddi oranda işsizlikle karşı karşıya kalınmıştı. Marx bu durumu kapitalist sistemin içinden gelen bir zaylflık olarak nitelendirmişti. Devletin en uç seviyedeki demokratik yapılarda dahi kapitalist burjuva sınıfinı bir aracı haline geldiğini ve bu yüzden sadece o kesimin ihtiyaçlarına hizmet etmekte olup çalışan kesimin aleyhine davrandığını iddia etmiştir. Burjuva sınıfı bugünkü Neoklasik sistemde yaşandığ $\breve{g}_{1}$ gibi tekelleşirken çalışan kesim gitgide fakirleşmekteydi. $\mathrm{Bu}$ durum iki kesim arasında refah anlamında uçuruma sebep olmaktaydı. Marksist sosyalist devletin kurulması ile üretim araçları devlet elinde toplanarak sosyal refah seviyesinden herkes faydalanmış olacaktı. Ancak çeşitli politikalarla ve değişikliklerle bunu daha önce uygulayan bazı ülkeler sosyalist sistemin ortaya çıkmasına bir şekilde müsaade etmemiş oldular (Gencer ve Birol, 2014).

K. Marx, bunun yanında emek değer kuramı yönünden de Klasik ve Neoklasik ekolden ayrılmaktadır. Neoklasik iktisadın doğuşunda etkili olan Marjinalist görüşe göre değer, fayda kavramıla birlikte açıklanmıştır. Buna göre malın değeri piyasaya çıkan son birim malın sağladığı faydaya eşittir (Dudu, 2014). Neoklasik görüşün aksine, soyutlama kavramıyla ön plana çıan Marksist emek değer kuramı İngiltere'de 19. yüzyılda ortaya çıkan sınıf çatışmalarının anlaşılmasında önemli rol oynamaktadır. Emek değer kuramıyla K. Marx İngiltere'de 19. yüzyılda işçilerin kapitalist düzene sert tepki vermelerini sağlamıştır. Bu kuram ile serbest ekonomik yapı altında kapitalist sömürünün özünün kavranmasına destek olmuştur. Bu kuram gelişerek ve ilerleyerek kapitalizme karşı toplumsal ve hatta siyasal anlamda bir mücadele başlatılmasının temel unsuru haline gelmiştir. Marx bu kuram ile emek veren işçilerin ortaya koydukları değerin farkına varmalarını sağlayıp sermaye sınıfının aslında karşllığı verilmeyen bu emeğe nasıl el koyulduğunu göstermiştir (Koç, 2014).

19. yüzyılın ortalarına dek Klasik iktisadi düşünce çeşitli eleştirilere karşın egemen iktisadi düşünce okulu olarak kalmayı başarmıştır. Ancak bu yıllardan sonra eleştirilerin dozu artmış ve Klasik iktisat okulunun görüşleri sorgulanır hale gelmiştir. Teoriden ziyade eleştiriler daha çok yöntem konusundan kaynaklanmıştır. Örneğin Malthus'un nüfus teorisi yaklaşımı böyledir. Bunun dişında, o yıllarda ivme kazanan sanayileşme ve kentleşme ile beraberinde yaşanan olumsuz sosyal problemler eleştirilerin odak noktası olmuştur. Kişisel eleştirilerden öteye geçemeyen 
durum A. Marshall'ın Neoklasik iktisat teorisini kurmasiyla önemli bir noktaya gelmiştir. Neoklasik iktisat okulu, Klasik iktisat okuluna tamamen karşı çıkmamakla birlikte onu çeşitli yönlerden eleştirmiş ve ondan ayrılan yönleri olmuştur. Neoklasik iktisat akımı Klasik iktisat akımından ayrı olarak piyasanın kendiliğinden dengeye geleceği düşüncesine karşı çıkmış ve piyasa ekonomisinin kendiliğinden sosyal refahı sağlayamadı̆̆ı durumlarda devletin ekonomiye müdahalede bulunması gerektiğini belirtmiştir (Güngör, 2006).

1929 yılında yaşanan Büyük Buhran ve ekonomik etkileri sonrası İngiltere'de ortaya çıkan işsizlik artışının sebebini Keynes, Klasiklerden farklı olarak tasarrufların yatırımlara dönüşmemesi olarak ortaya koymuştur. $\mathrm{Bu}$ dönemde Klasik iktisat akımının ekonomi yöntemleri ve politikaları artan şekilde tartışılır hale gelmiştir. "Bırakınız yapsınlar bırakınız geçsinler" görüşünün arkasındaki serbest piyasa yapısı yerini devlet müdahaleciliğine, "her arz kendi talebini yaratır" düşüncesi ise yerini "her talep kendi arzını yaratır" düşüncesine bırakmıştır. Özellikle arz yönlü politikaların ekonomik krizin sorunlarına çözüm bulamayışı, efektif talep anlayışı ile ekonomideki sorunlara çözüm bulan Keynesyen görüşün ön plana çıkmasını sağlamıştır. Buna göre ekonomideki herhangi bir sorunun çözümü toplam talep ayarlamaları ile çözülebilecektir. Klasiklerin aksine Keynesyen görüş ekonominin kendiliğinden dengeye gelemeyeceğini, devletin ekonomide varlığının gerekli olduğu üzerinde durmuştur. Klasik teoride ekonomide belirlilik hâkim iken Keynesyen ekonomide belirsizlik ve geleceğe yönelik beklentiler önem arz etmektedir (Güngör, 2006; Tüleykan, 2010).

\section{Neoklasik İktisat Akımına Getirilen Eleştiriler}

Neoklasik iktisat ekolü 1870'li yıllarda sanayi kapitalizminden finans kapitalizmine doğru yaşanan bir Marjinalist devrimle
(Sarfati, 2010) ortaya çıkan günümüz ana akım iktisadıdır. Burada Neoklasik ekolün ana akım olarak bahsedilmesinin temel sebebi Amerikan kapitalizminin varlı̆̆ıdır. Ana akım olarak kastedilen şey iktisat eğitiminin temelini oluşturmasından ve iktisadi çalışmaların büyük kısmında referans kayna ğı olmasından kaynaklanmaktadır (Dudu, 2014).

Bir asrı geçen ana akım ekolün egemenliği iktisattaki ders programlarından ideolojik yaklaşıma kadar kendini derinden hissettirmiştir. Klasik ekole getirdiği eleştiriler ve çözüm önerileri sonrası ortaya çıkan Neoklasik ekol iktisada getirdiği farklı bakış açıları, uygulamalar ile dikkat çekmiştir. Geliştirdikleri iktisadi yasaların evrensel olduğunu iddia ederek (Dudu, 2014) bu yönde çalışmalar gerçekleştirmişlerdir. En çok eleştiri aldıkları kısım da evrensel olduğunu iddia ettikleri bu yasalar üzerinden gerçekleştirdikleri çalışmalar üzerinden olmuştur.

Neoklasik iktisat ekolünün Klasik iktisat ekolü ile benzer felsefi ve ideolojik yaklaşımları olmakla birlikte Klasik iktisat ekolünden bariz şekilde ayrılan görüşleri de mevcuttur. Neoklasik ekolün temel düşüncesi belli kısıtlar altında çıkar maksimizasyonu ya da maliyetlerde minimizasyon sağlamaktan geçmektedir. Azalan marjinal fayda prensibi ve değer kuramı Klasiklerden ayrılan diğer bir yönleri olmuştur. Üretim faktörlerinin ve malların ikamesi ile Klasiklerden farklı olarak emek değer kuramına değil öznel bir değer kuramı üzerinde durmuşlardır. Belki de en fazla eleştiri alıp kendilerinin de en fazla ilerleme sağlamaya çalıştıkları alan ise geliştirdikleri iktisadi olayların evrensel olduğunu iddia etmeleri olmuştur. Böylece iktisadı sosyal bilim olmanın ötesinde genelde doğa bilimleri ile özelde ise fizikle yakınlaştırmaya çalışmışlardır. Bunu gerçekleştirebilmek adına ise $\mathrm{ku}$ ramlarında evrensel olarak kabul edilebilecek olan matematik ve ekonometri ile olan ilişkilerini artırmışlardır (Bilir, 2018). İdeolojik çerçevede bu görüşler ile ön plana 
çıkan Neoklasik iktisat akım, iktisat dersi anlamında ise mikro iktisat alanında Klasik iktisat ekolünden yola çıkmakla birlikte makro iktisat alanında Keynesyen iktisat ekolünden yola çıkmışlardır (Birol ve Gencer, 2014).

\subsection{Post Otistik Iktisat Hareketi}

Post Otistik İktisat hareketi 2000 yllında Fransa'da bir grup iktisat öğrencisi tarafından internet üzerinden (Fullbrook, 2000) Ortodoks iktisat akımına yöneltilen sert eleştirilerle gündeme gelmiştir. Öğrenciler kendilerine adeta dikta edildiğini söyledikleri bir eğitim sistemini istemediklerini belirtmişlerdir. Aşırı matematik kullanımındaki rahatsızlıkların ortaya koyarak iktisadı sosyal bilim alanından uzaklaştı̆̆ı üzerinde durmuşlardır. Eleştirilerin odağında ana akım iktisat olan Neoklasik ekol olmakla birlikte, Neoklasik iktisat ekolün yaklaşımlarının gerçek yaşamla bağlantısız olduğu yönünde eleştiriler üzerinde durmuşlardır.

Özellikle iktisat eğitimi üzerinde yoğunlaşan eleştirileriyle egemen iktisada karşı oluşan Post Otist İktisat hareketinin kapsamm belirten "otistik" kelimesi dahi bilinçli olarak seçilmiştir. "Otistik" kelimesi burada anormal derecede sübjektiflik ve gerçek dünyadan çok hayali olan dünyayı yansıttığı (Ruben, 2012) anlamında kullanılmıştır. Otistik bilim toplumdan kendini soyutlamış, kendi ilgi alanı olan toplumsal yapıya yabancı olan ve bu yapinın bireyleri arasındaki ilişkileri, bireylerin gerçek ihtiyaçlarına göre olması gerekirken, güçlünün çıkar ilişkilerine göre ilişkileri düzenleyen bilim olarak tanımlanmıştır (Evranos, 2004).

Post Otistik İktisat hareketi öncelikle Fransa'da gerçekleşmiştir. Ardından iktisadın kalesi olarak nitelendirilebilecek İngiltere ve Türkiye'de dahil olmak üzere bütün dünyada etkisini etkin bir şekilde hissettirmiştir. Yayınlanan bildiriler, gösteriler, tepkiler art arda gerçekleşmiştir. Hareketin öncelikle Fransa'da başlamış olmasının en önemli iki sebebinden bir tanesi Fransa'da her daim tarihsel anlamda radikal eğilimlerin güçlü olmasından kaynaklanmaktadır. İkinci olarak ise Fransa'da entelektüel gelenek olarak sosyal bilimlerin yerinin çok ayrı olmasindan ileri gelmektedir (Erdölek, 2012).

Post Otistik İktisat Hareketi ilk çıktığ zamanlarda Türkiye'de de etkisini hissettirmiştir. "İktisat" dergisi Post Otistik İktisat Hareketine yer vererek bir sayısını iktisat eğitimine ayırmıştır. Bu sayıda bazı önde gelen akademisyenler makale yayınlayarak destek vermişlerdir. Ankara ve İstanbul'dan bazı üniversite öğrencileri bildiriler yayınlayarak harekete desteklerini dile getirmişlerdir. Ancak Türkiye'de bu tepki dünya geneline göre bakıldığında istenen düzeyde olmamıştır (Erdölek, 2012). Fransa'da iktisat öğrencilerinin ana akım iktisat akımına tepkisi ile başlayan ve başta Nobel ödüllü Robert Solow'da (Aydın, 2016) olmak üzere bazı ünlü iktisat akademisyenlerinin destekleriyle dünya çapına yayılan Post Otistik İktisat eleştirisinin üzerinde durdukları belli başlı konular vardır (Fullbrook, 2000). Öğrenciler yaymlanan bildiride öncelikle iktisat programlarında öğretilen teorik bilgilerle gerçek yaşamdaki uyumsuzluk üzerinde durmuşlardır. Öğretilen iktisadi bilgilerin hayali olduğunu (Raveaud, 2001), gerçek yaşamda ortaya çıkan sorunları çözme konusunda yetersiz kaldığını belirtmişlerdir. Burada derste öğretilen iktisatla gerçek hayattaki iktisat arasında bir bağ kurulamamasının önemli sebeplerinden biri, bir takım iktisadi kavramların ya da uzun matematiksel/istatistiksel formüllerin sonuçlarının gerçek hayatta tam olarak ne anlama geldiğinin yeterince anlatılmamasıdır (Ruben, 2012). İkinci olarak değindikleri nokta iktisatta matematik kullanımının iktisadı açıklamak için bir araç olması gerektiği, amaç haline gelmemesi noktasında olmuştur. Matematiğin iktisattaki yoğun kullanımına karşı çıkmışlardır. Burada iktisat öğrencilerinin üzerinde durdukları nokta matematiğin iktisattan tamamen kaldırılması değil (Erdölek, 2012) sinırlı kullanılması yönünde olmuştur. Üçüncü eleştiri 
olarak iktisat derslerinde çoğulculuk istediklerini, programlarda sadece Ortodoks iktisat düşüncelerinin dogma gibi öğretilmemesi gerektiğini bildirmişlerdir. İktisadın sosyal bir bilim dalı olduğu, bilimin de zit görüşler, eleştirel yaklaşımlar olmadan ilerleyemeyeceği yaklaşımından hareketle sadece ana akım iktisat üzerinden derslerin işlenmesinin yanlış olduğunu belirtmişlerdir. Son olarak ise iktisat akademisyenlerine çağrıda bulunarak hemen harekete geçmeleri gerektiklerini, eğer hızlı ve kapsamlı bir değişim yaşanmazsa sayıları azalmaya başlayan iktisat öğrencilerinin bu alanı terk etmeye devam ederek sayılarının giderek azalacă̆ını belirtmişlerdir.

Yukarıda bahsedilen Post Otistik İktisat Hareketinin egemen iktisadi akıma karşı eleştirilerinin yanında çeşitli çözüm önerileri de getirmişlerdir. Öncelikle mikro ekonomi derslerinde daha az matematik kullanımına yer verilmesi gerektiğine değinilirken iktisadi analizlerin, yorumlamaları iktisat öğrencilerinin yanında toplum tarafından da anlaşılması gerektiği üzerinde durulmuştur. Anlatılanlar temel ekonometrik modellemeler şeklinde siralanmak yerine (Evranos, 2004) daha farklı ve anlaşlabilir yolların denenebileceği belirtilmiştir. Disiplin olarak iktisadın egemen iktisat anlayışın homojenliğinden siyrılıp (Altunöz, 2013) farklı fikirlere de yer vererek tarih, sosyoloji, psikoloji gibi diğer disiplinlerden daha fazla yararlanması gerektiği üzerinde durulmuştur. Çoğulculuk sorunu olarak adlandırılan ve eleştirilen durum ise Neoklasik iktisat ekolün dışında iktisat programlarında diğer kuramlara yer verilmemesidir. 2008 Global krizinin henüz gelişme aşamasında tüm dünyaya yayılmadan önlenebileceği ancak Neoklasik iktisat ekol dışında kuramların çözüm önerilerine yer verilmediği için krizin dünyaya yayılmasına engel olunamadığı belirtilmiştir (Tutar ve Eren, 2011).

\subsection{Neoklasik Íktisat İdeolojisinin Küresel Politikalar Üzerindeki Etkisi}

Neoklasik iktisat ekolünün iktisat bilimi kapsamında etkinliği her alanda kendini hissettirmektedir. Bu etkinlik kendi ideolojik ve felsefi görüşleri dışındakileri reddetmesiyle rahatsız edici bir duruma gelmiştir. Neoklasik iktisat ekolünün bu etkinliği sadece ideoloji olarak kalmayı hayatın akışı içinde de kendini göstermektedir. Bu konudaki en ciddi durum özellikle 2000'li yıllara yaklaşırken ve sonrasındaki kriz dönemlerinde IMF ve Dünya Bankası'nın önermiş olduğu politikaların temelinin Neoklasik iktisat ekolüne dayanması ve krizlere çare olamayışı olmuştur. Özellikle Amerika'da önemli köşe yazarları IMF ve Dünya Bankası'nın egemen iktisat akımına dayanan politikaları, çözüm önerileri ciddi şekilde eleştirmişlerdir (Dudu, 2014). Bu eleştirilerin artma sebebi ise özellikle 1980 sonrasında Neoklasik iktisat ekolüne bağlı görüşlerin kalkınma ve büyüme politikalarma yön vermesine rağmen büyüme ve kalkınma bir yana bir de küresel krizle karşılaşılması olmuştur (Barca, McCann, ve Rodríguez-Pose, 2012; Yavan, 2013).

Neoklasik iktisat akımı piyasaya belli şartlar dışında devletin müdahale etmesini istemezken Dünya Bankası ve IMF ile kendi kuramlarını politikalarıyla devlet kanalıyla değil ama kurumsal anlamda aslında piyasaya müdahalede bulunmaktadır. Özellikle 1980 sonrası meydana gelen Doğu Asya, Rusya, Latin Amerika ve Türkiye gibi birçok krizler sonrasında IMF ülkelere belli politika dayatmalarında bulunmuş ve ülkeler krizden çıkmak bir yana ekonomik anlamda daha kötüye giden durumlar da olmuştur. Artan işsizlik oranları bu duruma en önemli örnektir. Stiglitz gibi önemli iktisatçılar da bu başarısızlıkların sebebi olarak Dünya Bankası ve IMF kurumlarını işaret etmişlerdir. Hatta Stiglitz IMF ve Dünya Bankası'ndaki iktisatçıların aldıkları eğitimleri bile eleştirmiştir. Egemen iktisadın ana akım olarak bahsedilmesinin Amerika kapitalizminden kaynaklandığını 
belirtmişken burada IMF ve Dünya Bankası politika önerilerinin Amerika kapitalizminin devamı mahiyetinde olduğunu ise belirtmekte fayda vardır (Acar, 2005).

Küresel ekonomi aktörlerinin önemli kurumlarından IMF politikaları son dönemde sıkça başarısız sonuçlar vermiş ve bu kapsamda her kesimden eleştiriler almıştır. Özellikle Doğu Asya krizi sonrası IMF'nin ülkelere verdiği maddi yardımlar karşılığında daraltıcı politikaları benimsetip özelleştirme yoluyla yapısal uyum politikaları altında büyümenin aksine yoksulluklara sebebiyet verdiği görülmüsstür. IMF'nin dayattığı ekonomi politikalarının küresel finans sistemlerinin çıarları doğrultusunda hareket ettiği yönünde şüpheler artmıştır. Krize giren ülkelerin yardım almak uğruna IMF gibi kuruluşların önerdiği politikaları kabul etmek zorunda olmaları başka çareleri olmadığ 1 anlamina gelmektedir. $\mathrm{Bu}$ zor durum belli bir ideolojik, felsefi görüş tarafından yönlendirilen IMF politikalarını istemeyerek de olsa kabul etmek anlamina geliyordu. Aslında ana akım ideolojik ve felsefi görüşleri ve özellikle çoğulculuk konusunda yaşanan sıkıntı sadece kriz yaşanan ülkelerde kendini gösterip o bölgelerde eşitsizliği, krizin derinliğini, sosyal adaletsizliği artırmamaktadır. Neoklasik iktisadi akımın 2008 krizine çözüm üretemeyişinin yanında Amerika'da 1980 sonrasında yaşanan firsat, gelir ve servet eşitsizliğinin de 2008 krizine adeta zemin hazırladığı aşikardır. Dolayısıyla Dünya Bankası ve IMF politikalarının Neoklasik ideolojik yaklaşımı ile kriz yaşanan ülkelerde eşitsizliği ve sosyal adaletsizliği artırdığı görülmüsstür. Politikaların bu olumsuz etkisi sadece kriz yaşanan ülkelerde değil, ana akım iktisat ekolünün doğuş yeri olan Amerika'da da yaşanmıştır. Bu durum sadece ekonomi aracılığıyla uygulanmayıp siyasi ve hukuki kimliklerle de yapılanlar meşru hale getirilmektedir (Stiglitz, 2016).

Krizdeki ya da borçlu ülkelerin, ülkenin yapısal sorunlarının kontrolünü kreditörlere vermesi yeni olmayıp küreselleşmenin er- ken dönemlerin ortaya çıkan bir olgudur. Meksika, Venezuela ve Mısır gibi ülkelerin mağduriyet durumları bu şekilde ortaya çıkmıştır. 2. Dünya Savaşı'ndan sonra bu kez aktörler değişip IMF ülkelerin ekonomik özgürlüklerini teslim almaya başlamıştır. Ülkelerin ekonomik özgürlüklerinin IMF gibi kurumlara teslim edilmesi sadece yoksul ülkelerde yaşanmayıp Avrupa ülkelerinde de yaşanmaya başlamıştır. Yakın dönemde Yunanistan ve İtalya'da yaşananlar bu duruma en güncel örnekler olmuştur. Özellikle yoksul ve kriz dönemindeki ülkelerde IMF gibi kuruluşların önerdiği politikaların yerine getirilmemesi, bu kez bu ülkelerin kredi derecelerinin düşürülmesine ve verilen paraların geri çekilerek faizlerin yükseltilmesine neden olabilmektedir. Bu duruma somut bir örnek ise 1990'll yllarda iki kez Brezilya'da başkanlık seçimini kazanma aşamasına gelmiş olan Luiz I. L. da Silva'nın Wall Street tarafindan yukarıda saydığımız tehditlerle karşı karşıya kalmasıdır. 2002 yllına gelindiğinde ise bu kez Goldman Sachs ülkedeki yatırımların tehlikeye gireceğini belirtmesine rağmen Brezilya halkı 8 yıl boyunca iktisadi bir istikrar sağlayan, büyümeyi destekleyip ülkedeki aşırı gelir adaletsizliği ile mücadele eden Başkan Lula'yı seçmiştir. Özellikle ülkeleri yatırımların geri çekileceği ve buna ilişkin kredi derecelendirme kuruluşları tarafından verilen harf notları ise inandırıcılığını yitirmiştir. Çünkü Goldman Sachs gibi kuruluşlar egemen iktisadın ideolojik, felsefi ve çoğulculuk karşıtı uygulamaları uğruna bir gün A notu verdiği ülkeye başka bir gün F notu verebilir hale gelmiştir (Stiglitz, 2016).

\section{3 İktisadın Doğa ve Sosyal Bilimlerle İlişkisi}

Bilimin sınırları ve çerçevesi tam olarak belirlenememekle birlikte genel anlamda doğa ve sosyal bilimler olarak iki şekilde tasnif edilmektedir. Bu ayrım yapılırken gözlem kaynağındaki farklılık diğer bir ifadeyle de- 
neysel durum, tarihsel kapsamm ehemmiyeti (ekonomik kurum ve davranışların tarihsel olarak değişim ve gelişimi) ve insanın var olan aktifliği kıstaslarından yararlanılmıştır. Farklı bilimlerin birbirini etkilemesi ve bu etkileşimi belirleyen temel fikirlerin net biçimde anlaşılamaması durumu entelektüel olarak sıkıntıya sebebiyet vermiştir. Bunun neticesinde doğa bilimi ile sosyal bilim arasındaki metodolojik birlik bilim felsefesi içinde en önemli tartışmalardan biri haline gelmiştir. $\mathrm{Bu}$ yöntembilimsel tartışmalar iki düzeyli olarak smıflandırılabilir. $\mathrm{Bu}$ smıflandırmalardan ilki yöntembilimsel yaklaşımların genel anlamda bilimsel tanımlamanın nasıl ve niçinlerini ortaya koymaya çalışırken ortaya çıkan farklılıkları barındırmaktadır. Bu tartı̧̧malar yöntembilimsel tekçilik yani doğa ve sosyal bilimlerin aynı yöntemi kullanması gerektiğini ifade edenlerle yöntembilimsel ikicilik yani doğa ve sosyal bilimlerin metodolojik anlamda farklı yöntemleri kullanması gerektiğini ifade edenler arasinda gidip gelmektedir. Diğer sinıflandırma ise araştırma konusu ve nesnesinin ele alınmasındaki bakış açılarında oluşan farklılığ ele almaktadır. Buradaki tartışma durumu ise parça-bütün ilişkisi çerçevesinde yaşanmaktadır. Yöntembilimsel tekçilik, bireysel düzeye indirgenemeyen bilimsel açıklamaları reddederken; yöntembilimsel bütüncülük, bütünü baz almayan açıklamalarm nesnellik iddiasında olamayacağını belirtmektedir. Yöntembilimsel tartısmaların ikinci düzeyi ise metodolojik anlamda tartışmalarının niteliğine göre farklılaşmalarını ele almaktadır (Durusoy, 2008; Demir, 2014).

Son yıllarda doğa ve sosyal bilimler arasında gerçekleşen yapisal bir dönüşüm mevcuttur. $\mathrm{Bu}$ dönüşüm uç durumlarda meydana gelip eksen kayması şeklinde yaşanır hale gelmiştir. Genelde sosyal bilimlerin ve özelde iktisadın kendi kapsamları içinde olan insan ve topluma dönük amacı gerçekleştirmekten uzaklaşıp diğer bilim dallarının sınırlarına girmiş olması eleştirilir hale gelmiştir. Özellikle 2. Dünya Savaşı yıllarından iti- baren iktisadın artan bir ekonometrik, matematik ilişkisine girmesi iktisadı matematiğin alt disiplini gibi görülmesine sebep olmuştur. Bu durum yöntembilimsel tekçilik tartışmalarının artmasına kadar gitmiştir (Durusoy, 2008).

İktisadın diğer bilim dallarıyla olan ilişkisi yeni olmamakla birlikte bilimlerin diğer bilim dallarıyla ya da alanlarıyla olan ilişkisi yadsınamaz bir gerçektir. İktisatta sosyal bilimler arasında diğer bilim dallarıyla etkileşimi fazla olan bir bilim alanıdır. Bu ilişkinin ilk aşamalarına gidildiğinde iktisadın fizikle olan ilişkisi dikkat çekmektedir (Acar, 2016). Newton'un yaptıklarından etkilenip, bunu sosyal bilimlere uygulamaya çalışan A. Smith'ten itibaren bu ilişkinin arttığı görülmüştür (Daniel ve Sornette, 2008). İktisadın fizik ile olan ilişkisi sadece Ortodoks iktisatla kalmayıp K. Marx ile de kendini göstermiştir. Marx'ın Kapital isimli eserinde bu durumu görmek mümkündür. Kitapta potansiyel sermaye kavramindan bahsedilmesi, bu kavramm doğrudan potansiyel enerji kavramından ya da D'alambert'in zımni veya örtük hızlar ilkesinden türetildiğini göstermektedir. Bu kapsamda hareket eden K. Marx'da zımni veya örtük sermaye kavramı üzerinde durmuştur (Çakır, 2001).

İktisadın Newton fiziği üzerinde şekillenmesi

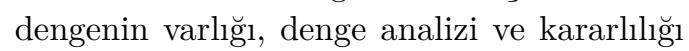
gibi temel yaklaşımlarm da bu kapsamda oluşmasına yol açmıştır. Ancak bilinmesi gereken durum gerçek iktisadi yaşamda belirsizlik ve dengesizlik durumu (Eren, 2012) hakimdir. Zaten iktisadın fizik ile oluşturmaya çalıştığ 1 bu ilişki bilimin nesnelliği çerçevesinde gerçekleştirilmeye çalışılmıştır. Ancak bu gerçekleştirme iktisat açısından bir yerden sonra ilerlenemeyecek duruma gelmiştir. Çünkü kimya, biyoloji, fizik gibi doğa bilimleri ideolojik bakış açısına sahip olmamasına karşı iktisat biliminin içerisinde ideolojik faktörlerin yer alması ve bundan doğal olarak kopamaması iktisadın kimya, biyoloji, fizik gibi bilimlerle ilişkisi sınırlı olmuştur (Yalçınkaya, 2006). 
Buradaki sınır iktisadın fizik gibi mutlak gerçekleri olan (Tutar ve Eren, 2011) bir doğa bilimi olmamasından kaynaklanmıştır. Toplumsal ve siyasi beklentiler, bireysel ve kurumsal tercihler, zevkler, gelenekler zaman içinde değiştikçe iktisatta kendi içinde değişime uğramaktadır. $\mathrm{Bu}$ durum iktisadı evrensel kabul gören kanunları olmayan ve sosyal bir bilim özelliğinde tutmuştur. Çünkü iktisat evrensel kanunları ortaya çıkarmaya çalıştığında toplumdan uzaklaşmakta ve kendi içinde belirsizlik hâkim olmaya başlamaktadır.

Dünyada iktisatla fizik ve daha sonrasinda iktisatla matematik arasında yaşanan bu gelişmeler olurken Türkiye'de de 1950'li yıllardan başlayarak sırasıyla mühendislik ve tıp bilimlerindeki eğitim alanlarında popüler olmuştur. Ancak iktisat ve finans alanlarının maddi koşullarının öğrencilerin ilgisini çekmesi matematik tabanlı öğrencilerin sosyal bir bilim olan iktisada doğru eğilimlerini artırmışıtır. Bu eğilim Neoklasik iktisat okulu savunucularının matematik tabanlı oluşunun, iktisadı matematiğe yaklaştırma eğiliminde olduklarının sebepsiz olmadığının en önemli kanıtlarındandır (Tutar ve Eren, 2011). Görüldüğü gibi geçmişten günümüze doğa bilimler ile sosyal bilimler arasında yaşanan metodolojik birlik, bilim felsefesi anlamında önemli bir tartışma konusu haline gelmiştir. $\mathrm{Bu}$ tartışmalar iktisadın ideolojik, kurumsal ve tarihsel yönünün ihmal edilmesi noktasina gelmiştir. Bunun da ötesinde iktisadın doğa bilimleriyle ilişkisi iktisada sınırlama ve kısıtlamalar getirmiştir (Durusoy, 2008).

İktisadın fizik bilimini kullanmaya çalışmasının asıl amacı ise fiziğin bilimsel dili olan matematiği içselleştirerek kesinliğe ulaşmaktır. Ancak sosyal dünya ile tümdengelim yöntem arasindaki uyumsuzluk kendini burada net şekilde göstermiştir. İktisat disiplini bu anlamda gerçekdışı varsayımlara ve kurgusal dünyaya yönelerek araştırma alanını matematiğe adapte etmeye çalışmıştır. Belki bu alanda beklenen ilerleme sağlanmış olmasına karşın sosyal gerçeklikten ve iktisat biliminden hızla uzaklaşılmıştır. Analiz sadece sayısal bir duruma indirgenmiş, kısıtlanmış ve sınırlı hale getirilmiş, bu yüzden de iktisadı, insanı oluşturan toplumsal gerçekliğin önemli bölümünü analiz dışında bırakmıştır (Acar, 2016).

İktisadın doğa bilimleriyle ilişkisinin aksine sosyal yapılar sürekli değişim ve gelişim içinde olduklarından dolayı doğa bilimlerine göre yer ve zaman koşullarına daha fazla bağımlıdır. Çünkü iktisatta birey, metodolojik bireysel bir yapı içerisinde hareket eder. Bu yaklaşımın temel varsayımına göre analizler birey baz alınarak gerçekleştirilir. Metodolojik bireyciliğe dayanılarak hareket edildiğinde ekonomideki bireylerin faydasının maksimize hale geleceği belirtilir (Kul ve Yüksel, 2018). Bir fizikçi aynı kütleyi herhangi iki farklı yerde atmasinda ayn hareket düzeyini yakalayacağını bildiği halde bu durum iktisatçı olarak iki farklı yerde firmaların aynı şartlara sahip olabileceğini söyleyemez. Bunun söylenememesinin en temel sebebi ise insanlarm belirsizlik ortaminda karar almaları ve bu kararı her zaman rasyonel bireycilik anlamında gerçekleştiremeyip inançlar ve ideolojilerin devreye girmesinden kaynaklanmaktadır (Acar, 2016). Bu yönüyle özelde iktisat genelde ise sosyal bilimler, doğa bilimlerinden farklıdır. Çünkü inançlar gerçeği etkileyecektir. İnançlar doğa bilimlerini değiştirmeyecektir. Ancak iktisadi sistemin nasıl ve ne yönde hareket ettiği yönündeki inançlar onun gerçekte nasıl işlediğini etkileyecektir (Stiglitz, 2016).

İktisadi süreç içerisinde bireyin rasyonellik, psikolojik, ideolojik, hukuki, sosyolojik, siyasi şartlar altında karar aldı ̆̆ düşünülürse iktisadın diğer sosyal bilimlerden ayrıştırılması düşünülemez (Ruben, 2012). Nitekim Türkiye'deki iktisat akademisyenleri de bu görüşü destekler nitelikte iktisadın diğer bilim dallarıyla ilişkisi bağlamında psikoloji, sosyoloji, tarih, siyaset bilimi, hukuk alanlarındaki iktisat ilişkini genel anlamda önemli görmüşlerdir 
(Çevik ve Umutlu, 2019). İktisadın diğer sosyal bilimler ilişkisinin güçlü olmasının sebebi ise sosyal olaylarm ampirik yollarla kanitlanması zor olmasindan kaynaklanmaktadır. İnsan ilişkilerine göre hareket edildiği için sosyal bilimlerle ilişkisi daha fazla ön plana çıkmaktadır. Odak noktasında insan olduğu için iktisadın diğer sosyal bilimlerle de ilişkisi haliyle önemli hale gelmektedir. $\mathrm{Bu}$ ilişkinin Neoklasik iktisadın çoğulculuk sorunu ile sekteye uğraması ise eleştirel bir tutumla bakılmasına sebep olmuştur (Baloğlu, 2004).

Her ne kadar Neoklasik iktisat, iktisadın içerisinde egemen iktisat rolünden dolayı özellikle diğer sosyal bilimlere yer vermese de iktisatta Neoklasik akım ile birlikte amaç haline getirilmeye çalışılan matematiksel modellemeler, ana akım kuramların krizlere çözüm üretemeyip problemleri daha da derinleştirmesi gibi sebeplerden dolayı iktisatta Heterodoks yaklaşımların ortaya çımasına engel olamamıştır. Özellikle iktisat biliminde ideolojik ve felsefi anlamında çok yapılı durum ve çoğulculuk belki de iktisadı popüler kılan en önemli özelliklerden biri olmasına karşın Neoklasik iktisat akımı ile birlikte bu durum ortadan kalkmıştır. Diğer bilim dallarının görüşlerine ve çözüm önerilerine egemen iktisat olma yolunda ilerleyebilmesi adına kapalı olması Ortodoks iktisadın en çok eleştirilen yanlarından biri olmuştur (Eren ve Uysal, 2017).

\section{4 Íktisatta Matematik Kullanımı}

İktisat doğa bilimlerinin aksine sosyolojik bir bilim dalı olup zamana, mekâna ve şartlara göre değişebilen bir bilim dalıdır. Diğer sosyal bilim dallarmda olduğu gibi insanla ilişkisi kapsamında (Kaleci ve Buluş, 2016) iktisadın diğer sosyal bilim dallarıyla olan ilişkisi yadsınamaz bir gerçektir. İktisat biliminin temelinde insan olduğu için psikoloji, sosyoloji, tarih, siyaset bilimi ve hukuk ile ilişkisi Türkiye'de ki iktisatçılara yönelik yapılan çalışmada da dile getirilmiştir. Sadece sosyal bilimler ile değil sosyal bilimler dışında matematik ve ekonometri/istatistik bilimleriyle ilişkisi de önemli görülmüştür. Ancak burada matematik ile ekonometri/istatistik biliminin iktisada negatif etkisinin de olduğunu belirtmişlerdir. Şöyle ki; "Günümüzde iktisat giderek gerçekçi olmayan varsayımlarda bulunan matematiksel modellere bağlı hale gelmiştir." ve "Ekonometri ve istatistiğin kullanımı çok da beklenen yararı sağlamamakta, geçerli iktisat bilgisi üretmek için anlaml sonuçlar ortaya koyamamaktadır." önermelerine önemli derecede katılım göstermişlerdir (Umutlu, 2019).

Ancak iktisatçıların özellikle diğer sosyal bilimlerle ilişkisi bu denli özel ve önemli görülmesine karşın son dönemde öğrencilerin toplumu kapsamlı şekilde gözlemleyerek yorum yapma yeteneği ve gelişimi kazandıracak entelektüel alanlar iktisadın dışında tutulmaya başlanmıştır. Üniversitelerde psikoloji ve sosyoloji dersleri müfredattan çıkarılmakta, iktisadın öne sürdüğü politikalar direkt politik neticelere yol açmasına rağmen siyaset bilimi de sınıflarda tartışılmamaktadır. Ayrıca Batı'da ki üniversitelerin önemli bir bölümünde iktisat disipliniyle doğrudan ilişkili olan iktisat metodolojisi, düşünce tarihi, iktisat tarihi gibi dersler de müfredattan çıarılmaya başlanmıştır. Bunun yanında iktisatta matematiğin ve ekonometri/istatistik kullanımı ise giderek artmakta ve iktisatçıların sosyal bilim olma özelliğinden uzaklaşıp iktisadın insanla ve toplumla ilişkisinden kaynaklanan çok çeşitli yapısını sinırlandırmaktadır (Acar, 2016).

İktisatta matematik kullanımı iktisat biliminin doğuşuna kadar götürülürken özellikle 2. Dünya Savaşı yıllarından sonra artan bir kullanımı görülmektedir (Doğruel, 2012). İktisat bilimindeki artan matematik kullanımı akademik anlamda da kendini göstermiştir. $\mathrm{Bu}$ artışın yaşanması iktisatçlları çabuk ve basit makale yazmaya ittiği belirtilmelidir. Bilimsel dergilerdeki yaşanan bu matematikselleşme olgusu dünyadaki prestijli dergilerden birinde 
yaşanmıştır (Bilgin, 2006). American Economic Review'de ki derginin sayıları ilerledikçe iktisadi anlamdaki akademik çalışmalarda artan derecede matematik kullanımı dikkat çekmiştir (Debreu, 1991). İktisatta matematik kullanımının özellikle 2 . Dünya Savaşı yıllarından sonra artmasının en önemli sebebi 1929 ekonomik krizi ve sonrasında yaşanan savaşlarla ekonomideki kötü gidişatın kısa süre içerisinde düzeltilebilmesi adına bilimsel anlamda daha çabuk, etkili ve uygulanabilir sonuçlar için sayısal verilerin kullanılmasından kaynaklanmaktadır (Yaşar, 2014). Özellikle son yüz yılda Neoklasik iktisat matematiksel modelleme ile istatistiksel yöntemleri iktisat biliminde egemen hale getirmiştir. Bu egemenlik öyle bir seviyeye ulaşmıştır ki artık iktisadi anlamda karşılaşılan her sorun nicel verilerle değer atfetmeden ve ölçülmeden dile getirilemez bir hale getirilmiştir (Meçik, 2015).

A.Marshall'a göre iktisatçıların, iktisatta yoğun matematik kullanımının artmasının önemli bir sebebi, matematiği iktisatta kesinlikle kullanmak zorunda olduklarından değil iyi bir iktisatçı olma yolunda ilerlemeleri için gerekli olduğunu düşündüklerinden kaynaklandığını belirtmiştir. Nitekim Marshall'da matematiğin iktisatta yaygınlaşmasında önemli bir isim olarak göze çarpmaktadır. Marshall iktisatta matematiğin kullanımını desteklemesine rağmen iktisatta matematik kullanımının doğru bir şekilde gerçekleşmediği takdirde matematiğin anlaşılmaz bir duruma geleceğini belirtmiştir. Bu yüzden iktisatta matematiğin kullanımı konusunda dikkatli olmak gerektiği üzerinde durmuştur (Acar, 2001). Bu konuda yaşanmış önemli gelişmelerden bir tanesi ise matematiği iktisat bilimine uyarlamış olan iktisatçılardan T. Koopmans, tüketim fonksiyonunu istediği şekilde anlatamayan J. Tobin'i öğrencilere matematiği anlatmak için değil iktisadı anlatmak için burada olduğunu hatırlatarak eleştirilerini iletmesi olmuştur (Kumcu, 2005).

İktisatta matematiğin yoğun kullanımı tek başına bir problem olmayıp iktisadın sosyal bilim özelliğini kaybetmesinden ve toplumsal sorunlarla ilişkisini azaltmasından kaynaklanmaktadır (Monaghan, 2003). Oysa iktisatta makro sorunlar olan işsizlik, yoksulluk, gelir dağılımda yaşanan sıkıntılar gibi birçok durum toplumsal sonuçlara neden olmaktadır. Bu yüzden de iktisadın sosyal bilim özelliğinden uzaklaşıp doğa bilimi olan matematikle yoğun şekilde kullanılması düşünülemez. Zaten iktisadın üretici ve tüketici davranışlarının temsilcisi olan bireyin tercihlerini yansitması bu durumu desteklemektedir (Durusoy, 2008).

Matematiksel yöntemlerde ısrarcı olmak iktisatçıyı bir seçimle, adeta bir kısıtla (Guerrien, 2017) karşı karşıya getirmektedir. Ya iktisadın ilgi alanında olan bazı sosyal gerçeklikler matematiksel formülasyon haline getirilemediği için analiz dışında kalacaktır ya da matematikselleşme uğruna sayısal olarak ifade edilemeyecek büyüklükler için çalışmayı zor durumda birakacak tahminlere başvurulacaktır. Her iki durum da iktisatçıyı sınırlayacak ve belki de matematiksel yorumlar sebebiyle sosyal bilimlerden uzaklaşılacaktır. Burada Neoklasik iktisada getirilen eleştiri matematiğin iktisattan tamamen soyutlanması değil araç olarak kullanılmaya devam edilmesi yönündedir. Eleştirilerin sertliği ve artışı iktisadi yöntemlerde matematiğin araç olmaktan çıkıp amaç haline gelmesinden kaynaklanmaktadır (Acar, 2016).

İktisadın matematiksel yönü öyle bir hale gelmiştir ki üniversitelerde iktisat eğitimcilerinin, araştırma ve öğretim görevlilerinin seçiminde, matematikteki ve ekonometride ki maharetleri onları birkaç adım ön plana çıkarır hale gelmiştir. Bu kapsamda iktisadın ödül mekanizması da bu yöne doğru evrilmiştir. Örneğin J. Stiglitz birçok özgün ve orijinal çalışması olmasına karşın uzun zamandır gözlemsel yolla bilinen bir durumu matematiksel olarak gösterdiği için Nobel ekonomi ödülüne layık görülmüştür. Bilimsel anlamda değer verilen yeni, özgün çalışmalar değil matematik- 
sel anlamda ulaştığı başarılar olmuştur (Guerrien, 2005). Bu anlamda ödül mekanizmasında tümevarım yöntemlerden çok tümdengelim yöntemlerin kullanıldığı çalışmaların ön plana çıkarıldığına dikkat çekilmektedir. Samuelson, Hicks, Koopmans, Debreu, Allies, Arrow gibi bilim insanlarmn aldığı ödüllerde olduğu gibi matematiksel formüllerin ödüllere yansıması görülmektedir. Bu durum sadece matematiksel formül olarak dikkat çekmemekte, 20. yüzyllın ikinci yarısından itibaren artan ekonometri kullanımıyla birlikte bu durumun ödül mekanizmasına da yansıdığı net şekilde görülmektedir (Lindbeck, 2007).

Nobel ekonomi ödüllerine kadar uzanan ana akım iktisat okulunun bu durumu kendini sadece matematiksel anlamda da göstermemektedir. Ana akım iktisadın ödül mekanizması ile amaçladığı durum egemen paradigmanın güçlü bir yapıya sahip olmasını sağlamaktan geçmektedir. Özellikle ana akım iktisat akımının kendisini ifade etmek ve çalışmalarını meşru hale getirmek için kullandığı ve klasik ders kitaplarında da büyük ölçüde hakimiyet kurduğu iki alan mikro ve makro iktisat olmuştur (Soyak, 2003). Bu durumu ödül mekanizması çerçevesinde desteklemek için dünya çapında prestije sahip olan Nobel ekonomi ödülü ile de desteklemek ana akım iktisadın önünün açılması adına yeterli olabilecektir. $\mathrm{Bu}$ kapsamda Nobel ekonomi ödülleri için tüm dönemde verilen ödüller göz önüne alındığında verilen ödüllerin yaklaşık \%80 oranında mikro ve makro iktisat alanındaki iktisatçılara verilmesi önemli bir durumdur (Zahka, 1990; Soyak, 2003). Nobel iktisat ödüllerindeki bu durumun bariz şekilde yapıldı̆̆ına örnek ise Joan Robinson ile John Nash'in yaşadığı hikâye olmuştur. 1994 yllında Nobel iktisat ödülünü almaya hak kazanan John Nash esasında bir iktisatçı olmadığını açı şekilde beyan etmesine rağmen egemen yani Neoklasik iktisada yönelik bir çalışma olup piyasa mekanizmasını rekabetçilikle değil de iş birliği ile daha da güçlendirmeye yönelik bir yapı sunan oyun teorisine yönelik katkılarıyla bu ödüle layık görülmüştür. Ancak ünlü İngiliz iktisatçı Joan Robinson ana akım iktisat akımina muhalif görüşleri sebebiyle bu ödüle layık görülmemiştir. J. Robinson'un ödüle layık görülmemesinin en önemli sebebi olarak ise, Nobel komitesinin ödülü Joan Robinson'a vermesi halinde Robinson'un kamunun önünde bu ödülü almayı reddedip egemen iktisadı tüm dünyanın önünde eleştirmesi şeklinde gösterilmiştir (Millmow, 2002).

İktisatta matematik kullanımının aşırı olduğu durumlarda iktisadın sosyal bilim olma özelliğine zarar verdiğine yukarıda detaylıca değinilmiştir. Ancak iktisatta matematiği tamamen soyutlamak gereksiz ve yanlıştır. Nasıl ki iktisat bilimi diğer sosyal ve doğa bilimleriyle temas halindeyse matematikten de kendi bilimsel yapısına katkı verdiği ve amaç haline gelmediği sürece yararlanması gereklidir. İktisatta matematik kullanımı amaç haline gelmediği sürece araç olarak kullanılarak iktisadın etkinliğini artıracağ $\breve{1}_{1}$ da söylenebilir. İktisatta bilimsellik olgusu geçerli bir durumdur. Bu durum ilgilenilen mikro ve makro bazlı çalışmaların nedenlerinin tanımlanmasını gerektirir. $\mathrm{Bu}$ süreçte matematiksel yöntemler ölçümlerde gerekli olan durumu test edilebilir şekilde ifade etmek için yardımcı oluyorsa iktisat için önemli bir araç görevi görecektir. Ancak burada unutulmaması gereken durum iktisadın bilimselliğinin bahsedilen matematiksel yöntemlerle kazanmadığıdır. Matematik ve istatistiksel sonuçlar sosyal bir bilim olan iktisadın toplumsal sorunları anlatma durumunda bir araç olabilecektir. Karmaşı sistemlerin çözümünde iktisat biliminin matematik, ekonometri gibi bilimlerden yararlanması doğaldır. Ancak bunun daha fazla ileriye gidip iktisadı da kendi içinde karmaşık bir yapıya dönüştürmesi eleştirilmektedir (Durusoy, 2008).

İktisat biliminde bazı durumlarda söz ile anlatılamayacak olaylarla karşı karşıya kalınabilir. Matematiğin de bir dil olduğu göz önüne alınırsa sözlü anlatımdan zi- 
yade matematiğin dili daha kesin, net ve anlaşılır olduğu için iktisatta araç olarak kullanılabilir. Çünkü matematiğin yapısı içinde, iktisat bilimine katkısı olabilecek zengin teoremler bulunmaktadır. İktisatçının yapacağı varsayımları benimsemesinin önüne geçip analizlerin ideolojik ve felsefi etkilerden korunmasını sağlayabilir (Kaleci ve Bulus, 2016). İktisat biliminde büyüme, enflasyon, işsizlik gibi makro ekonomik konular olduğu gibi fayda maksimizasyonu, maliyet analizleri gibi mikro ekonomik bulgular da mevcuttur. Bu bulgularm ortaya konulmasında ve açılanmasında iktisat tek başına yeterli olamayabilir. Bunun için matematiğin iktisat bilimi içindeki araç olma özelliğinden faydalanılması faydalı olabilecektir (Evranos, 2004).

\section{Sonuç}

Marjinalist bir devrim neticesinde ortaya çıkan ana akım iktisat okulu Amerikan kapitalizmi ile varlığını oluşturmakla birlikte özellikle iktisat eğitiminde ve iktisat çalışmalarında egemen iktisat olma yolunda ilerlemiştir. Klasik iktisadi akımla benzer görüşlere sahip olmasına karşın ondan net şekilde ayrılan tarafları da mevcuttur. Egemen iktisat anlayışı çerçevesinde iktisat eğitimi alanında ideolojik ve felsefi görüşlerini kabul ettirmeye çalışmışlardır. İktisatta aşırı matematik kullanımı, çoğulculuk problemi, iktisadi kuramlarındaki gerçek hayattan kopuk görüşleri onlarm eleştirilmelerine sebep olmuştur. Bu eleştirilerin sonucunda 2000 yılında hareketin isminden ortaya çıtığı ülkeye kadar düşünülmüş organizasyonel bir hareket olan Post Otistik İktisat Hareketi ortaya çıkmıştır. Bazı belli iktisatçıların da katılımıyla internette yayınlanan bir bildiri ile tüm dünyada etkisini hissettiren hareket sıradan istek ya da eleştirilerle değil elle tutulur belli başlı konularm altında durarak özellikle akademisyenlere çă̆rı yapmışlardır. Özellikle ilk çıktığı dönemde etkisini her yerde hissettiren ve olumlu tepkiler de alan hareket ilk çıtığ göre ana akım iktisat akımının eleştirileri dikkate almamasindan dolayı son dönemde etkisini yitirmiştir. Etkisini yitirmesindeki ana etmen ise ana akım iktisadın egemen iktisat yapisıyla her alanda kendini etkin şekilde hissettirmesinden kaynaklanmaktadır. İktisatta matematik kullanımının yanı sıra Neoklasik iktisat akımının çoğulculuk problemi sebebiyle kendi dışndaki iktisat akımlarının ideolojik ve felsefi görüşlerine yer vermeyişi ve bunun neticesinde 2008 krizine kendi çözüm önerisi olmamasının yanında alternatif çözüm önerilerinin de önünün kapatılması eleştirilerin doruğa ulaşmasına sebep vermiştir. Neoklasik iktisadi akımın egemen iktisat olma yolundaki politikaları özellikle IMF ve Dünya Bankası aracılığıyla yoksul ve krizdeki ülkelere uygulanan yaptırımlar sonucunda artan eşitsizlik, yoksulluk ve gelir dağılımındaki adaletsizlik bu kurumlarında ana akım iktisadın ideolojik ve felsefi yapısı çerçevesinde hareket ettiklerine yönelik tepkilerin delillerle birlikte artmasina sebep olmuştur.

Özelde iktisatta matematik kullanımı, genelde ise iktisadın doğa bilimleri ilişkisi yeni olmayip A. Smith'e kadar giden bir yapıdır. Ancak özellikle 2. Dünya Savaşı yllarından sonra iktisatta artan matematik kullanımı ve iktisadın adeta matematiğin bir alt dalı gibi görülmeye başlanması iktisatçlların yanında iktisat dışındaki bilim insanlarını da rahatsız etmiştir. Ancak iktisadın, önüne geçilemeyen doğa bilimleri ilişkisi iktisadın odak noktasındaki bireyin sahip olduğu psikolojik, sosyolojik, hukuki, siyaset bilimi gibi sosyal bilim dallaryyla olan yadsınamaz durumu iktisadın aslında sosyal bilimle olması gereken yoğun ilişkisinin doğa bilimlerine kaymasının tezatlı̆̆ını ortaya koymustur.

Doğa bilimlerinin, sosyal bilimlerin zamana, mekâna ve şartlara göre değişmesinin aksine herkes tarafindan her yerde kabul gören bir bilim dalıdır. Buna karşın iktisadın sosyal bilimlerin yanında doğa bilimleri ile olan ilişkisi matematikte dahil olmak 
üzere kabul edilen bir durumdur. Ancak 2 . Dünya Savaşı'ndan sonra iktisat eğitiminden bilimsel yayınlara kadar iktisattaki yoğun matematik kullanımı bu durumun bir ilişkiden ziyade ideolojik ve felsefi görüş çerçevesinde şekillenen sistematik bir olgu olduğunu göstermiştir. Artık iktisatçılar matematiği kendi alanlarında ilerlemek adına bir gereklilik olarak görmeye başlamıştır. $\mathrm{Bu}$ yöndeki ilerleme kendini iktisat ödüllerinin en üst merkezi olan Nobel ekonomi ödüllerinde de kendini göstermiştir. Alınan ödüller ideolojik ve felsefi yaklaşımlara göre verilmeye başlanıp ana akıma muhalif görüşlere sahip bilim insanlarının çalışmaları hak etmesine rağmen ödüllere layık görülmemiştir. Bu kapsamda yaşanan bütün bu sistematik süreç iktisatta matematik kullanımının kademeli dahi olsa azaltılması gerektiğini göstermektedir. İktisat sadece iktisatçllar tarafindan değil toplum tarafindan da anlaşılabilecek, matematik ve ekonometrik terimlerin karmaşasından kurtulabilecek bir yapıya kavuşturulmalıdır. İdeolojik, felsefi politikalar uğruna dikta edilen mikro ve makro iktisadi eğitimler tekrar gözden geçirilmelidir. 2008 krizinde de somut olarak yaşanılan çoğulculuk probleminin nelere sebep olabildiği ve gelecekte böyle bir krizde aynı şeylerin yaşanmamasının garanti olmadığ 1 bilinerek hareket edilmelidir. Bu kapsamda diğer felsefi görüşlere yer verilerek öğrencilerin derslerde politika, siyaset bilimi, metodoloji, psikoloji, sosyoloji, tarih, doktrinler tarihi tartışabilir duruma gelmesi sağlanmalıdır. Amerika'da 1980 sonrası başlayıp günümüzde artan gelir dağglımındaki adaletsizlik, eşitsizlik ve ekonomideki istikrarsız yapı ana akım iktisadın ideolojik yapisına teslim edilmemelidir. Post Otistik İktisat Hareketinin ortaya çıkmasıyla etkisinin hissedildiği Türkiye'de de özellikle iktisat eğitimi alanında önemli adımlar atılmalıdır. İktisat eğitimi alanında iktisadın sosyolojik bir disiplin olduğu bilinerek iktisat tarihi, iktisadi doktrinler tarihi, iktisat sosyolojisi, iktisat felsefesi gibi derslere daha fazla yer verilmelidir. Ezberci bir modelle değil analiz süreci ile birlikte öğrencilerinde sürece aktif olarak katılması sağlanarak iktisatta matematik ve ekonometriye araç bağlaminda yer verilmeli ve iktisat politikalarının anlaşılması sağlanmalıdır. Analiz sürecinde temel ekonometrik modeller lisansüstü düzeyde öğretilip çalı̧̧malarda amaç olarak değil araç olarak kullanmaları sağlanmalıdır. İktisadın disiplinler arası bilim olma yönünden yararlanılarak öğrencilerin yorum, analiz kabiliyetleri artırılmalıdır. Verilen derslerde mikro ve makro iktisat anlaminda ezberci bir sistem değil felsefi, ideolojik, doktrinler tarihi gibi görüşlere sahip olmaları sağlanmalıdır.

\section{Kaynakça}

Acar, G. T. (2001). İktisatçlar ve insanlar: bir yöntem çalışması. İstanbul: İletişim Yayınları.

Acar, G. T. (2005). Neoklasik iktisat teorisine metodolojik açıdan eleştirel bir yaklaşım (Yüksek Lisans Tezi). İstanbul: İstanbul Üniversitesi Sosyal Bilimler Enstitüsü İktisat Teorisi Anabilim Dalı. https://tez.yok.gov.tr/UlusalTezMerkezi/ TezGoster?key=wBmNpkQC9Nhi90NLW7E7 -RdIqPwQLT13ag05gVrBM3iSVX -IYAJbwn3mvYdTtSXo.

Acar, G. T. (2016). İktisadi değiştirmek. İstanbul: İletişim Yayınları.

Altunöz, U. (2013). Egemen neoklasik iktisata eleştirisel yaklaşım: post otistik iktisat ve 2008 küresel krizinin post otistik analizi. Uluslararası Sosyal Araştırmalar Dergisi, 7, 14-22. http://www. sosyalarastirmalar.com/ cilt7/sayi29pdf/altunoz_utkux.pdf.

Aydın, Y. (2016). Post otistik iktisat: iktisat eğitimi ve neoklasik iktisat eleştirisi. Selçuk Üniversitesi Sosyal Bilimler Enstitüsü Dergisi, 35, 35-47. http://dergisosyalbil.selcuk.edu.tr/ susbed/article/view/1200.

Baloğlu, B. (2004). İktisadın sosyal boyutu. Sosyoloji Konferansları Dergisi(29), 99-119. https://dergipark.org.tr/en/pub/ iusoskon/issue/9531/118972.

Barca, F., McCann, P., ve Rodríguez-Pose, A. (2012). The case for regional development intervention: Place-based versus place-neutral approaches. Journal of Regional Science, 52(1), 134152. doi:10.1111/j.1467-9787.2011.00756.x

Bilgin, C. (2006). İktisatta matematiksel yaklaşım sorunu. Uluslararası İktisadi ve İdari Incelemeler Dergisi, 2006/2, 6984. https://dergipark.org.tr/en/pub/ sosyoekonomi/issue/21064/226804. 
Bilir, H. (2018). Neoklasik iktisadın tanımlanmasına yönelik bir deneme. Itobiad: Journal of the Human 8 Social Science Researches, 7(2). doi:10.15869/itobiad.387221

Birol, Ö. H., ve Gencer, A. H. (2014). Neoklasik iktisat ve neo-klasik sentez. Trakya University Journal of Social Science, 16(1). https://dergipark.org.tr/en/pub/ trakyasobed/issue/30214/326159.

Çakır, N. (2001). Neoklasik İktisat. In Iktisat'ın dama taşları: ekoller, kavramlar, iz bırakanlar. İstanbul Üniversitesi İktisat Fakültesi Mezunları Cemiyeti İktisat Dergisi Yayınları.

Çevik, S., ve Umutlu, H. (2019). Türk iktisatçlar arasında devletin ve piyasanın rolüne ilişkin görüşlerde uzlaşma ve uzlaşmazlıklar (Yayımlanmamış Konferans Bildirisi). İstanbul: 10. Uluslararası Siyasal İktisat Konferansı (ICOPEC 2019).

Daniel, G., ve Sornette, D. (2008). Econophysics: historical perspectives. In R. Cont (Ed.), The encyclopedia of quantitative finance (pp. 1-7). Wiley.

Debreu, G. (1991). The mathematization of economic theory. The American Economic Review, 81(1), 1-7. http://www.jstor.org/ stable/2006785.

Demir, O. (2014). İktisat metodolojisi. İstanbul: Sentez Yayıncilık.

Doğruel, F. (2012). Iktisat öğretiminde matematik (Tartışma Metni). Ankara: Türkiye Ekonomi Kurumu. http://www.tek.org.tr/files/disc/ dt126.pdf.

Dudu, H. (2014). Neoklasik iktisat kuramının genel çerçevesi ve eleştirisi. Aydınlanma 1923, 48(48), 25-38. http://www.aydinlanma1923.com/index . php/AYD23/article/viewFile/227/227.

Durusoy, S. (2008). İktisat biliminin yeri ve yöntemi neden sorgulaniyor. Uluslararası İnsan Bilimleri Dergisi, 5(1), 1-26. http://kisi.deu.edu.tr/selim.sanlisoy/ iktisatbilimininyerive\%20yontemi.pdf.

Erdölek, O. (2012). Baska bir iktisat mümkün (mü)?"Post Otistik Iktisat". Iktisat ve Toplum Dergisi, 23. https://www.iktisatvetoplum .com/iktisat-ve-toplum-dergisi-sayi-23/.

Eren, E. (2012). Yerleşik iktisatta içerik kayması ve paradigma değişikliği (Tartı̧̧ma Metni). Ankara: Türkiye Ekonomi Kurumu. http://www.tek.org .tr/files/disc/dt123.pdf.

Eren, E., ve Uysal, E. (2017). İktisatta yeni heterodoks gelişmeler. Kırklareli Üniversitesi İtisadi ve İdari Bilimler Fakültesi Dergisi, 6(2), 134-151. https://dergipark.org.tr/en/pub/ klujfeas/issue/31239/339969.

Evranos, F. (2004). Post otistik iktisat tartısmaları (Yüksek Lisans Tezi). İstanbul: Marmara Üniversitesi Sosyal Bilimler Enstitüsü. https ://tez.yok .gov.tr/UlusalTezMerkezi/TezGoster?key= Keh6sQzap4ZTp8dqWP1H1LvDIRbjFtMhIi43TJ9QIG DewfntSzikKbvNz55ydEjD.

Fullbrook, E. (2000). post-autistic economics newsletter (Paecon Newsletter Subscription Call).
Paecon.net. http://www . paecon.net/PAEReview/ wholeissues/issue2.htm.

Gencer, A. H., ve Birol, O. H. (2014). A. smith ve klasik okul, $k$. marx ve marksist sosyalizm, jm keynes ve keynesgil devrim ve daha sonraki gelişmeler (Yayımlanmamış Konferans Bildirisi). Istanbul: Beykent Universitesi: International Conference on Eurasian Economies. https://www . avekon.org/papers/1166.pdf.

Guerrien, B. (2005). A science too human? economics. Post-Autistic Economics Review, 24. http://www.paecon.net/PAEReview/ issue24/Guerrien24.htm.

Guerrien, B. (2017). Neoklasik Iktisat teorisi (M. Dönmez, H. Şahin, ve E. Tokdemir, Çev.). İstanbul: İletişim Yayınları.

Güngör, K. (2006). İktisadın tarihine kısa bir bakış ve merkantilizmden günümüze İktisadi düşünceler. Afyon Kocatepe Üniversitesi Sosyal Bilimler Enstitüsü Dergisi, 14, 1-41. https://www.researchgate.net/profile/Kamil _Guengoer/publication/266607898_IKTISADIN _TARIHINE_KISA_BIR_BAKIS_VE_MERKANTILIZMDEN _GUNUMUZE_IKTISADI_DUSUNCELER/links/ 5699f54b08aea1476943f054.pdf.

Kaleci, F., ve Buluş, A. (2016). Matematik Iktisadı ele mi geçiriyor (Tech. Rep.). Konya: Necmettin Erbakan Üniversitesi: I. International Social Sciences and Muslims Congress / ISSMC-2016. http:// sempozyum.konya.edu.tr/depo/sem11/files/ 57f5e5ab2c806c1720fec558117d07bd.pdf.

Koç, Y. (2014). Marksist emek değer kuramı ve emperyalist dönemde kapitalist sömürü. Bilim ve Ütopya Dergisi, 239, 113. https://e-dergi.bilimveutopya.com.tr/ e-arsiv/ana-tanricadan-gunahkar-kadina.

Kul, G. E., ve Yüksel, C. (2018). İktisat ile siyaset bilimini birleştiren İki farklı sistematik yaklaşım: Kamu tercihi teorisi ve bağımlı gelişme teorisi. Yönetim ve Ekonomi Araştırmaları Dergisi, 16(3), 89-104. doi:10.11611/yead.394991

Kumcu, E. (2005). İktisat eğitimi üzerine düşünceler (3) (Tech. Rep.). Hurriyet.com. http://www.hurriyet.com.tr/iktisat -egitimi-uzerine-dusunceler-3-343711.

Lindbeck, A. (2007). The sveriges riksbank prize in economic sciencies in memory of alfred nobel. The Nobel Foundation's Internetmuseum, 137. http://perseus.iies.su.se/ alind/Links/ NobelKOMPLdec07.pdf.

Meçik, O. (2015). Sosyal sermaye ve verimlilik ilişkisi: Literatür arştırması. 1 (Tech. Rep.). Konya: Necmettin Erbakan Üniversitesi: Uluslararası Uygulamalı Bilimler Kongresi "Sosyal Sermaye". http:// sempozyum.konya.edu.tr/depo/sem11/files/ 57f5e5ab2c806c1720fec558117d07bd.pdf.

Millmow, A. (2002). An ignobel scandal. Post-Autistic Economics Review, 13. http://www.paecon.net/PAEReview/ wholeissues/issue13.htm.

Monaghan, P. (2003). Taking on 'rational 
man' dissident economists fight for a niche in the discipline. Post-Autistic Economics Review. http://www.paecon.net/PAEarticles/ ChronicleJan03.htm.

Raveaud, G. (2001). Teaching economics through controversies. Post-Autistic Economics Review, 5. http://www. paecon.net/PAEtexts/Raveaud1 .htm.

Ruben, E. (2012). Iktisat öğretimi üzerine bir yazın taraması, (Tartışma Metni). Ankara: Türkiye Ekonomi Kurumu. http://www.tek.org .tr/dosyalar/05-RUBEN.pdf.

Sarfati, M. (2010). Marjinalist dönüşüm ve bugünün dünyası. Sosyal ve Beşeri Bilimler Dergisi, 2(1), 77-84. http://sobiad.org/e JOURNALS/ dergi_SBD/arsiv/2010_1/10metin_sarfati.pdf.

Soyak, A. (2003). Nobel İktisat Ödülleri Üzerine bir yorum. Finans $\&$ Politik ve Ekonomik Yorumlar Dergisi, 256, 74-87. https://mpra.ub.uni -muenchen.de/2983/1/MPRA_paper_2983.pdf.

Stiglitz, J. E. (2016). Eşitsizliğin bedeli (O. İşler, Trans.). İstanbul: İletişim Yayınları.

Tüleykan, H. (2010). Tarihsel süreçte ekonomide devletin yeri, gelişimi ve yeniden yapılandırılması. Bütçe Dünyası Dergisi(33), 86114. https://www.researchgate.net/profile/ Hayrettin_Tueleykan/publication/317259379

_Tarihsel_Surecte_Ekonomide_Devletin_Yeri

_Gelisimi_ve_Yeniden_Yapilandirilmasi/

links/592eacb2a6fdcc89e762f411/Tarihsel

-Suerecte-Ekonomide-Devletin-Yeri-Gelisimi

-ve-Yeniden-Yapilandirilmasi.pdf.

Tutar, E., ve Eren, M. V. (2011). Post otistik iktisadın 2008 global ekonomik krizine bakışı: Türkiye için bir durum değerlendirmesi. Adıyaman Üniversitesi Sosyal Bilimler Enstitüsü Dergisi, 7, 299-314. http://dspace.adiyaman.edu.tr:8080/xmlui/ handle/20.500.12414/1724.

Umutlu, H. (2019). Devlet ve piyasa arasında iktisatçlar: iktisatçıların devletin ve piyasanın rolüne ilişkin görüs ve tutumları (Yayımlanmamış Yüksek Lisans Tezi). Konya: Selçuk Üniversitesi Sosyal Bilimler Enstitüsü. https:// tez.yok.gov.tr/UlusalTezMerkezi/TezGoster ?key=Mir21XQK1dkmQ9Ige3PZbj8oehKfEOQ5X2puw _vvV7D67k60BhPpsu8ZgfBGsfNN.

Yaşar, G. (2014). İktisat ve matematik (Yüksek Lisans Tezi). Giresun: Giresun Üniversitesi, Sosyal Bilimler Enstitüsü. https://tez.yok .gov.tr/UlusalTezMerkezi/TezGoster?key= 48XPj7KKQhKUgntkUiK03NfSVacC7JA4oEq4003 3Y1eossuLJSicnDbUCsBOgW7.

Yalçınkaya, T. (2006). Iktisat biliminin güvenilirlik sarsintısı bağlamında insanlar, iktisatçılar ve iktidarlar (Yayımlanmamış Konferans Bildirisi). İzmir: Karaburun Bilim Kongresi: Bilim ve İktidar, Bildiriler Kitabı. http://kisi.deu.edu.tr/timucin.yalcinkaya/ Insanlar ,\%20Iktisatcilar\%20ve\%20Iktidarlar .doc.

Yavan, N. Y. (2013). Küresel kriz sonrası bölgesel kalkınma politikalarında yeni yaklaşımlar: Dünya bankası, avrupa birliği ve oecd'nin yaklaşımları (Tech. Rep.). İstanbul: Fatih Üniversitesi: Coğrafyacılar Derneği Yıllık Kongresi Bildiriler Kitabi. https://dspace.ankara.edu.tr/ xmlui/bitstream/handle/20.500.12575/41659/ Yavan, $\% 20$ Nuri. pdf? sequence $=1$.

Zahka, W. J. (1990). The nobel prize economics lectures as a teaching tool. The Journal of Economic Education, 21(4), 395-401. doi:10.1080/00220485.1990.10844685 


\title{
Post Autistic Economics Movement: A Critical Approach
}

\author{
HASAN UMUTLU (1) ${ }^{1}$
}

Received:20.01.2020; Revised:11.03.2020; Accepted:26.04.2020

\begin{abstract}
Neoclassical economics theory which resulted in a marginalist revolution is in a position to dominate in economics education and economics studies being of American capitalism. Philosophical and ideological acceptances of the main stream economics have taken its effect up to Nobel Economics Prizes from policies of The World Bank and The International Monetary Fund. The main stream economics in economic education field teaches as dictate itself ideological and philosophical theories. Therefore the main stream economics has isolated through economics social sciences like schools of economic thought, history, political sciences, sociology, psychology. Within this scope, pluralism problem and theory remote from real life, increasing mathematics use in economics has led to the rise in criticism against the main stream economics. This criticism became organized with Post Autistic Economics Movement as a result of a notice prepared by students in France in 2000. The movement criticized diversely the main stream economics and has been expanded to world. Post Autistic Economics Movement has been thought up to country that it showed up in France from name of "autistic". In study has been mentioned from inequality, inequality in income distribution that the main stream economics took place with policies The IMF and The World Bank. In study has been concluded that mathematics became an aim for economics. Neoclassical economics has been seen in editions and education of economics effect as philosophical and ideological. Neoclassical economics has been indicated that it's ideological and philosophical opinion has affected foundations as Nobel and The World Bank, IMF.
\end{abstract}

JEL codes: A11, A12, A14, A20, B13

Keywords: Neoclassical Economics, Post Autistic Economics, Social Science, Economics and Mathematics

\section{Extended Summary}

Neoclassical economics is a theory resultant from marginalist revolution. It has been dominant to economics for about a century. The reason for this has been due to The American Capitalism. So, it is called main stream economics theory. The main stream economics theory is particularly effective in two areas. While one of those is

1 Department of Economics Doctoral Program, Institute of Social Scienses, Eskisehir Osmangazi University, Turkey. (e-mail: hasandnyl@gmail.com) the economics education, other is reference in the studies of economics. Although Neoclassical economics theory has similar opinions with Classical economics theory, it has different opinions from Classical economics theory. The different opinions from Classical economics theory are principles of diminishing marginal utility, maximisation, subjective value model, universality of its opinions as ideological and philosophical. While the main stream economics has 
originated from Classical economics stream in microeconomics education, it has originated from Keynesian economics stream in macroeconomics education.

One of methodological discussions is classified as methodological dualism and methodological nomism. Methodological nomism indicates that social and natural sciences need to use same method. Methodological dualism indicates that social and natural sciences need to use different methods. These different discussions have risen because of rising mathematics ideas used in economics associated with World War II. Economists and other scientists criticize the main stream economics from various aspects. The most important of those has been mathematics use in economics. As soon as the relationship between natural sciences with economics isn't a new situation, the relationship between mathematics and economics has increased associated with the main stream economics. It has been because of rapid solution seeking for economy after World War II. At the start the relotionship between mathematics and economics has been seen as natural. But it has been criticized by other naturalists with economists that mathematics become aim for economics.

Post Autistic Economics has showed up because of increasing of mathematics used in economic models incompatible with real life, Neoclassical economics theory's universality as ideological and philosophical. Agents of Post Autistic Ecconomics' have warned economics academists in the world about energising. Because they haven't been pleased that they have economics education. It has been thought that Post Autistic Economics showed up in France and used 'autistic' word. Autistic' word reflects imaginary world. France has always had strong radical tendency historically. France has also had a special position in social sciences. Post Autistic Economics Movement has been spread to the world recently. The important economists in the world have supported this movement. When the movement showed up in France, it has been welcomed in Turkey. Turkish university students in Istanbul and Ankara have published a notice about the movement. But this situation hasn't been as well as rest of the world. The movement offered the need of less mathematics use in economics education, other disciplines out of Neoclassical economics, apprehensible by the public of economics as solution offers.

The focus of economics is human behaviours and human. Human is a social being. So, human is an important relationship with history, political science, psychology, sociology, history of economic thought. This situation has also been indicated by Turkish economists in the research work. The relationship between naturalalists as physics and mathematics, econometrics of economics hasn't begun with the main stream economics. The relationship between naturalalists and economics has begun with A. Smith and K. Marx. Although mathematics and econometrics have been seen as matter for economics by Turkish economists, it has also been thought that they haven't been seen as aim for economics. While the movement contiuned to criticize the main stream economics, the 2008 global crisis has been in America. Neoclassical economics theory haven't found a way out for this crisis. Criticism has risen in order not to be alternative theory opinions because of the main stream economics. Consequently Heterodox streams effectiveness have risen in reaction to the main stream economics. Although Neoclassical economics movement don't want state intervention in the market, the thing in itself interferes to the market with The International Monetary Fund (IMF) and The World Bank with itsself opinions ideological and philosophical. Thus the main stream economics imposes on to the market itself theories. Countries intervened by The IMF and The World Bank have became worse economically. Countries that experienced the crisis have became worse especially on inequality, inflation, 
unemployment, development. The most important example in this situation has been increasing inequality in America after 1980. Greece and Italy have been lowered credit rating one's grade fort his reason that the countries haven't adapt policies The Foundation of Goldman Sachs. The main stream economics opinions have tried to affect election of Brazil government with The Foundation of Goldman Sachs. But Brazil public has not allowed to interfere itself economies Foundation of The Goldman Sachs.

Economists like R. Solow and W. Leontief, P. Samuelson, J. Hicks, J. Stiglitz have expressed that they have ailed from increasing mathematics used in economics. They have indicated that this situation has too affected Nobel Economics Prizes. It is generally approved that mathematics used affected genius Nobel Economics Prizes. For example, although J. Stiglitz have had many genuine and original academic study, he have just had Nobel Economics Prize with a mathematics economics study. Samuelson, Hicks, Koopmans, Debreu, Allies, Arrow have too had Nobel Economics Prize with a mathematics study in economics. Increasing mathematics use in economics hasn't just been seen with Nobel Economics Prizes. Mathematics use in The American Economic Review has risen significantly 80. issue in 1990 according to 30. issue in 1940. On the other hand, the main stream economics affected of Nobel Economics Prizes has remarked in educational field of the prize. Nobel Economics Prizes have been given to studies in field of microeconomics and macroeconomics education. Although John Nash have also indicated that he wasn't a economist, he have had the prize for his contributions the main stream economics. 